\title{
Tree Mix Pollen Antigen IgG Antibody Measurement
}

National Cancer Institute

\section{Source}

National Cancer Institute. Tree Mix Pollen Antigen Ig G Antibody Measurement. NCI

Thesaurus. Code C130102.

A measurement of the tree mix pollen antigen Ig G antibody in a biological specimen. 